This item was submitted to Loughborough's Research Repository by the author.

Items in Figshare are protected by copyright, with all rights reserved, unless otherwise indicated.

\title{
Social media, professional media and mobilisation in contemporary Britain: explaining the strengths and weaknesses of the citizens' movement 38 degrees
}

\section{PLEASE CITE THE PUBLISHED VERSION}

https://doi.org/10.1177/0032321716631350

\section{PUBLISHER}

SAGE @ The Author(s)

\section{VERSION}

AM (Accepted Manuscript)

\section{PUBLISHER STATEMENT}

This work is made available according to the conditions of the Creative Commons Attribution-NonCommercialNoDerivatives 4.0 International (CC BY-NC-ND 4.0) licence. Full details of this licence are available at: https://creativecommons.org/licenses/by-nc-nd/4.0/

\section{LICENCE}

CC BY-NC-ND 4.0

\section{REPOSITORY RECORD}

Chadwick, Andrew, and James Dennis. 2016. "Social Media, Professional Media and Mobilisation in Contemporary Britain: Explaining the Strengths and Weaknesses of the Citizens' Movement 38 Degrees". Loughborough University. https://hdl.handle.net/2134/27429. 
Social Media, Professional Media, and Mobilization in Contemporary Britain: Explaining the Strengths and Weaknesses of the Citizens' Movement 38 Degrees

\author{
Andrew Chadwick and James Dennis
}

New Political Communication Unit, Department of Politics and International Relations, Royal Holloway, University of London

\begin{abstract}
Digital media continue to reshape political activism in unexpected ways. Within a period of a few years, the internet-enabled UK citizens' movement 38 Degrees has amassed a membership of 3 million and now sits alongside similar entities such as America's MoveOn, Australia's GetUp!, and the transnational movement Avaaz. In this article, we contribute to current thinking about digital media and mobilization by addressing some of the limitations of existing research on these movements and on digital activism more generally. We show how 38 Degrees' digital network repertoires coexist interdependently with its strategy of gaining professional news media coverage. We explain how the oscillations between choreographic leadership and member influence, and between digital media horizontalism and elite media-centric work constitutes the space of interdependencies in which 38 Degrees acts. These delicately balanced relations can quickly dissolve and be replaced by simpler relations of dependence on professional media. Yet despite its fragility, we theorize about how 38 Degrees may boost individuals' political efficacy, irrespective of the outcome of individual campaigns. Our conceptual framework can be used to guide research on similar movements.
\end{abstract}

Keywords: mobilization; activism; engagement; social media; journalism

\title{
In Political Studies.
}

\author{
“Author's Accepted Manuscript," January 8, 2016, for UK Research Excellence \\ Framework eligibility. Please read and cite the final copyedited and typeset version of \\ this article, which can be found here: http://psx.sagepub.com
}

\footnotetext{
We thank Mary Francoli, David Karpf, and Kenneth Rogerson for their helpful comments on earlier drafts of this article; David Babbs and the 38 Degrees team for granting us access; and the three anonymous reviewers for Political Studies for encouraging us to think harder about our contribution. Some of the research in this article was presented at the International Political Science Association World Congress held in Montreal, Canada, July 19-24, 2014, and the American Political Science Association Annual Meeting held in Washington, D.C., August 28-31, 2014. We thank the participants in those meetings for their useful questions and comments. Any errors or shortcomings are our own.
} 
Founded in 2009, the UK citizens' movement 38 Degrees had, by 2015, attracted a membership of more than 3 million (38 Degrees, 2015). In this article we explain how 38 Degrees works by focusing on its 2013 Big Tax Turnoff campaign to compel a leading energy company, npower, to pay more tax. Our aim is to contribute to current thinking about digital media and mobilization by building upon and extending an enduring concept in this subfield: hybridity. We draw upon unique data including participant observation, campaign emails, social media content, online news articles, and interviews with 38 Degrees' leadership and a sample of members. In line with what we know about organizational hybridity among similar entities in other countries we find that 38 Degrees' leadership creates a wide range of online repertoires that foster individual autonomy and self-expression among its members. It switches its repertoires depending on the aims and focus of each phase of a campaign. It uses digital media, particularly email, online polls, and online petitions, but also social media discourse and metrics to enable grassroots members to shape campaign strategy in real time. And it maintains loose networks of individuals, technologies, and information that persist temporally and across a diverse range of issue campaigns.

We diverge from existing studies and open up new avenues of research by revealing the extent to which 38 Degrees rests on a hybrid mix of digital and professional media-centric repertoires. This hybrid campaign approach is designed not only to influence journalists but also serves to legitimate the movement to its own supporters by providing visible signs of a campaign's authenticity and its supporters' efficacy. This a source of power but also a source of vulnerability. Delicately balanced relations of interdependence between horizontalist digital media activism and professional media work can quickly dissolve and be replaced by simpler relations of dependence on professional media. We show that when professional media attention fades, interdependence turns to dependence, and a 38 Degrees campaign is more likely to falter. 
Explaining how and why this happens is one of our goals. To summarize our findings, it is not because 38 Degrees is adapting to 'mass media' logic and becoming just another elite-focused insider interest group whose primary goal is to get its stories in the press. Nor is it because professional media trivialize and marginalize 38 Degrees by personalizing its campaigns or framing it as a deviant 'protest' group. These are well-established explanations for movement 'failure' in earlier social movement research (see for example Gamson and Wolfsfeld, 1993; Gitlin, 1980; Rucht, 2004) but we find little evidence for these factors in the case of 38 Degrees campaigns.

38 Degrees' leadership certainly try to gain professional media coverage to convey campaign momentum to their dispersed membership base, but how this works is complex and differs from how it worked in earlier social movements (Gamson and Wolfsfeld, 1993; Gitlin, 1980; Rucht, 2004). Professional media coverage is a mirror used by the 38 Degrees core team to show its members that a campaign is still emergent and moving toward a successful outcome. It is seen as a credible means of reflecting the iterative successes of members' actions, thereby potentially expanding the scope and scale of future action. But as we show, 38 Degrees leaders and members both capitalize on the nature of today's media. Collectively, members produce large-scale, publicly visible informational traces of their own actions online: responses to issue-priority email polls, online petition signatures, social media comments, 'likes,' 'shares,' and retweets. These are mobilized in the leadership's interactions with professional media. The professional media coverage that follows is then used by the leadership to reinforce momentum and build individual members' efficacy, further increasing the likelihood that members will go on to participate in yet further online actions. Subsequent professional media coverage will again further increase the likelihood of member action, and so it goes on, in a virtuous circle. However, when this circle is broken, it becomes difficult to sustain a campaign's momentum. Despite this fragility and interdependence, we conclude our 
analysis with a note of cautious, if somewhat speculative optimism regarding how 38 Degrees' may, over time, boost individuals' political efficacy, irrespective of the outcome of individual campaigns.

\section{Organizational Hybridity and Hybrid Mobilization Movements: Augmenting the} Framework

Digital media continue to reshape political activism, and there is now a significant body of research that includes several substantial and influential book-length studies. ${ }^{1}$ An important strand in this literature is hybridity. We conceptualize this in two distinct though interrelated senses: organizational and media-systemic.

\section{Organizational Hybridity}

The idea of organizational hybridity begins from the perspective that interactions between the affordances of digital media and longer-term shifts toward personalization, political consumerism, and postmaterialist 'lifestyle politics' (Bennett, 1998) have created, among many other things, a new political form: the hybrid mobilization movement (HMM) (Chadwick, 2007). In the mid 2000s, only one example of this new form existed: MoveOn. ${ }^{2}$ Founded in the United States in 1998, by 2015 it had 8 million members. But over the last decade other HMMs have emerged (Kavada, 2012; Vromen, 2008; 2015; Vromen and Coleman, 2013). Australia's GetUp! was founded in 2005. Within a decade it had a selfreported one million members. SumOfUs, which facilitates multiple campaigns against corporate power, was founded in 2011 and now has more than 5 million members worldwide. 
Avaaz, an international movement founded in 2007 boasted an extraordinary 42 million members by 2015. And then there is the movement we examine here, Britain's 38 Degrees, founded in 2009 and soon likely to exceed 3 million members. ${ }^{3}$

What do we know about how these movements work? First, they cannot function without the complex spatial and temporal reconfiguring of political life that has been enabled by the widespread adoption and organizational embedding of digital communication. Second, mixing and switching between older campaign repertoires typically associated with parties, interest groups, and social movements, HMMs use digital media affordances to help them quickly adapt spatially, temporally, and institutionally — between online and offline action; from one campaign to another; and between elite-centric pressure strategies and member activism strategies. Third, given that digital media networks constitute almost (but not quite) the entirety of their organizational infrastructure, HMMs undergo an extraordinary amount of shape-shifting (Chadwick, 2007, pp. 285-286; Eaton, 2010, pp. 187-188). They lack the bureaucratic structures that make rapid structural change difficult for pre-digital organizations (Bimber, 2003; Bimber, et al., 2005; Bimber, et al., 2012). Instead, they mobilize their membership across loose affiliations of digitally-connected individuals. These affiliations periodically cohere and act before temporarily receding into inaction, only to cohere once more as the latent ties and informational infrastructure that unites them provide readily reactivated resources for action (Chadwick, 2007, pp. 285-286). We build upon previous research on MoveOn, GetUp!, and Avaaz that has explored what makes these new movements tick. ${ }^{4}$

\section{Media-Systemic Hybridity}


We contribute new understanding in three ways. First, we present the first detailed study of a 38 Degrees campaign. Second, we address a significant limitation in existing research on HMMs and digital mobilization more generally by demonstrating how 38 Degrees' digital network repertoires coexist interdependently with its strategy of gaining professional news media coverage. Third, while previous research has examined how these movements harness digital technologies such as email, blogs, and online petitions (Karpf, 2012), little is known about how social media, particularly Facebook and Twitter, function in HMMs. We begin to address this gap by explaining how social media comments and metrics function alongside other digital media in an interdependent relationship with professional media coverage.

Thus, our second conceptual starting point is that political communication now occurs in a hybrid media system built upon interactions among older and newer media logicswhere logics are defined as articulated bundles of technologies, genres, norms, behaviors, and organizational forms - in the reflexively connected fields of media and politics (Chadwick, 2013, p. 4). Actors in this system are articulated by complex and ever-evolving relationships based upon adaptation and interdependence and concentrations and diffusions of power. Actors create, tap, or steer information flows in ways that suit their goals and in ways that modify, enable, or disable others' agency, across and between a range of older and newer media settings (Chadwick, 2013, p. 4). As we show below, this approach focuses attention on how even the most obviously 'digitally-native' political activism has now evolved to the point where much of the daily practice involves the integration of older and newer media, in a hybrid mix.

Our approach in this article also jells with an emerging body of research that seeks to rejuvenate the older "media and movements" tradition most prominently associated with scholars such as Gitlin (1980). Mattoni and Treré's approach (2014) takes into account the 
role of everyday digital media technologies that enable the circulation of information for mobilization, but also the importance of targeting media professionals during periods of contentious action. Similarly, Vasi et al (2015) show how the environmental movement in the United States now uses documentary film to influence public opinion by integrating both elite media and social media strategies. We borrow from these insights and we also seek to show how 38 Degrees does more than simply feed stories to journalists. We show how polls, petitions, social media discourse, metrics, and crowdfunding are not only methods for aggregating members' views and actions; they also present members with accessible and visible signals of their own efficacy. And, in turn, these signals of efficacy are an essential part of hybrid media campaign logics that involve influencing professional media coverage.

\section{Data and Methods}

We build our argument by drawing upon data collected though interviews, participant observation, campaign emails, social media content, and online news articles (see Appendix). From April to July 2013 Dennis worked inside 38 Degrees headquarters and visited a variety of locations around Britain, contributing to the daily running of campaigns as a volunteer. During this period, Dennis conducted 22 semi-structured interviews with 38 Degrees core staff and a sample of ordinary members. Interviewees were selected through snowball sampling on the basis of contacts made during the participant observation period. All emails sent during the Big Tax Turnoff campaign were gathered through 38 Degrees' Blue State Digital suite of campaigning tools, to which we were given access. Posts were collected from 38 Degrees' Facebook page on a daily basis throughout the campaign. Twitter data was gathered using Sysomos MAP, a text mining platform which grants access to the full Twitter 
"firehose" archive. Using a custom search we collected campaign-related tweets during a sixweek period in April and May 2013, which allowed us to trace the relationship between campaign events and Twitter discourse about npower and tax avoidance. Finally, online news articles relating to the campaign were collected daily using Cutbot, a media monitoring service that collects news articles according to search criteria.

We acknowledge that our single-case research design limits the generalizability of our findings. However, the fieldwork on the npower campaign and earlier fieldwork for a related project by Chadwick (2013) allowed us to assemble a rich qualitative dataset on 38 Degrees' central staff and local members, whom we were able to probe on their general practice beyond this particular campaign. This gave us a strong sense that the Big Tax Turnoff campaign is broadly representative of other 38 Degrees campaigns. Moreover, in exploratory research, a thick account of a single case can have advantages over thin accounts of multiple cases. It can be useful for generating theory that might shape future empirical inquiry and it can be used to introduce variables that might have been missed by previous research (Geertz, 1973, pp. 3-30). These are our aims here. This case offers a window on 38 Degrees' campaigns' interdependence with professional media - an important variable that is largely absent from the extant work on HMMs and, indeed, many other accounts of digital activism.

\section{Analysis: The Big Tax Turnoff Campaign}

RWE npower is one of Britain's largest integrated energy companies, with 5.8 million customers and a multi-billion pound valuation. On April 16, 2013, its chief, Paul Massara, appeared before the House of Commons Energy and Climate Change Select Committee. Massara was there to give evidence to the Committee's inquiry into the lack of transparency surrounding UK energy company pricing and profits. ${ }^{5}$ During this highly-charged hearing, 
MPs asked Massara if he could confirm how much corporation tax npower had paid during the period from 2009 to 2011. In a startling admission, Massara said that his company 'will not have paid corporation tax in those three years.' Yet during this short period npower had made $£ 766$ million in operating profit. Immediate reactions to Massara’s remarks came from journalists on Twitter (see for example Hawkes, 2013a). Within a day 38 Degrees had launched a new national citizens' campaign, the Big Tax Turnoff, with the aim of forcing npower to pay more corporation tax.

The campaign began on April 17, 2013 - the day after the npower boss's remarks in Parliament - when the story was prominently covered by Britain's most popular daily paper, the Sun (Ashton, 2013). It was this professional media coverage that sparked the interest of 38 Degrees' staff in the organization's central London office. The decisions that drive 38 Degrees' leadership's priorities are generated from a range of qualitative and quantitative data embedded in routine practice at the organization's headquarters. Most important are a weekly online survey of a random sample of members, the analysis of formal and informal email feedback, and the collection of data from social media platforms, particularly Facebook (Interview 7, June 2013). 'Jonathan,' a campaigns manager and the staff member responsible for managing the Big Tax Turnoff campaign, told us how 38 Degrees members had frequently used these mechanisms in the past to prioritize tax avoidance (Interview 3, May 2013). The campaign therefore emerged from a confluence of the central team's ongoing priorities, their members' previous concerns, and, just as importantly, the perceived need to take advantage of headline news in the Sun, a populist, right-of-centre, and widely-read tabloid newspaper with a daily print circulation of 2.1 million and a unique website user count of 30 million per month. ${ }^{6}$

In an important difference from traditional interest organizations, 38 Degrees' central staff do not instrumentally 'choose' campaign issues. Instead, the organization's routines are 
structured so that members shape the leadership's decisions on which causes to pursue. By posting items that may be of interest to their members on Facebook, the central office is able to harvest social media data from a significant proportion of their membership, and, most importantly, it is able to do this rapidly in response to news cycles. Executive director David Babbs said that Facebook offers a consultative space that not only establishes clear and visible member support but also helps frame a campaign's core themes and the actions that might attract participants: 'When we are communicating with our members about an issue it gives us insights into the language they're using, the tone that they would expect us to adopt on it. Are they angry or scared, you know, those kind of things... It's a very good way of bringing our members into the room.' (Interview 7, May 2013).

After reading the Sun's article about Paul Massara's remarks in Parliament, the 38 Degrees central team reposted the article on their Facebook page and requested 'Click LIKE and SHARE if you think 38 Degrees should campaign on this. Comment and let npower know what you think of them.' Within a few hours this post had received 2,042 likes and 1,254 shares_-visible approval beyond the leadership's rough sense of the thresholds that must be breached for them to pursue a campaign. Campaigns manager Jonathan reflected on this process: 'We spotted the news story as a staff team... And then I popped it straight up onto Facebook and asked 38 Degrees members the normal, standard line, which was click "like" if you want to campaign on this, if you want to do something about this. We saw a really big response. We saw lots of 38 Degrees members chatting with each other online and that was the key reason why we decided to launch it so quickly' (Interview 3, May 2013).

38 Degrees' campaigns are therefore built upon the integration of digitally-expressed members' priorities and the leadership's perceived salience of issues in professional media. But this is not simply reactive opportunism by the core team, because members had already established tax avoidance as a clear priority in previous routine email poll responses going 
back several years. It is this constant monitoring of its members' attitudes that enables the organization to adapt and respond to news events. Particularly striking here is the speed and agility of this process. The movement rides the groundswell of enthusiasm and attention that surrounds an emerging news story while also generating norms of authenticity and legitimacy that animate real-time responses and the thrill of spontaneous mobilization, even if the contextual groundwork for that spontaneity has been completed in advance.

Next, on the basis of their Facebook straw poll, the leadership launched an online petition and shared the link on Facebook and Twitter, the 38 Degrees blog, and, most importantly, in an email to the full list of 38 Degrees members. Email is essentially 38 Degrees' organizational infrastructure, a trait it shares with MoveOn (Bimber et al, 2012; Chadwick, 2007; Karpf, 2012), GetUp! (Vromen, 2013), and Avaaz (Kavada, 2012). From the leadership's perspective, one is a 'member' of the movement by virtue of signing up to become an email recipient (Interview 5, May 2013).

Within a day of its launch, the online petition had attracted 70,000 signatures (Compton, 2013). Its agenda-setting power was immediate. The following day, April 18, several national newspapers covered the npower issue, including the Guardian (Macalister, 2013a), the Daily Mirror (Hiscott, 2013a), and the Sun (Hawkes, 2013b). But this time, all of these articles highlighted 38 Degrees' petition (Jarvis, 2013).

The 38 Degrees npower petition was not just a tactic to aggregate opinion. The leadership had also requested that when people sign the petition they should state whether they were a customer of npower, so the leadership were also able to publicize the number of petition signatories whom npower was in danger of losing as customers, unless it changed its tax reporting. This amounted to 14,000 petitioners. The petition, then, was aimed at elite news media but it was simultaneously a means of applying direct material pressure on npower. By encouraging its members to share the petition by email and on Facebook and 
Twitter, 38 Degrees were also able to generate more petition signatures while increasing the likelihood that npower's brand would suffer negative network contagion as the message spread online. Given that the average U.K. household spends $£ 1,345$ a year on natural gas and electricity (Department of Energy and Climate Change, 2014) the material impact on npower of up to 14,000 consumers moving their energy accounts would have been substantial—probably more than $£ 10$ million.

By meshing their campaign with an emerging news agenda that had originated with events in Parliament first mediated by newspaper journalists, 38 Degrees' central team were able to capitalize on the reach, influence, and legitimacy of professional media. Online petitions and social media metrics - likes, shares, retweets - are particularly suited to this approach. For news providers eager to frame stories around the resonance of ordinary individuals' collective outrage, they provide tangible evidence of citizen action. In other words, journalists can use online petitions and social media discourse and metrics to go beyond its routine reporting of the opinions of a full-time, professional leadership of a lobbying organization or think tank based in the familiar Westminster 'bubble.' In addition, these social media metrics were used by 38 Degrees staff as they urged the Guardian and the Sun to cover the campaign.

This hybrid logic was also in action in the form of personal stories from 38 Degrees members. A few days into the campaign, as the online petition reached 100,000 signatures, the leadership sent emails to the 14,000 npower customers whom it had identified had signed the petition, asking them to share their personal stories about the effects of high energy prices, as a means of keeping the cause 'in the news':

\section{Over 100,000 members of 38 Degrees have signed the petition telling npower to} pay its fair share of tax. Your support has helped rattle npower and got tax dodging 
back into the news.

But we need to keep up the pressure. The media have already shown interest in our people-powered campaign and chances are, it'll be in the news again next week. And one way to guarantee it increases the pressure on npower is to make sure they see their own customers in the news, saying they'll switch to another energy supplier.

\section{Can you help? Would you be willing to share your story as an npower customer? ${ }^{7}$}

This call for member involvement integrates three interdependent logics. First, the leadership's decision to use the petition as a means of gathering the email addresses of those of its members who were npower customers enabled it to activate those individuals through a micro-targeted email appeal. Second, without the authentic participation of these individuals - in creating their own personal and unique stories about what npower's tax avoidance meant to them - the appeal might have lacked resonance. As Vromen and Coleman (2013, p. 76) noted in their study of two campaigns by Australia's GetUp!, the use of affect, personalization, and storytelling, when skilfully deployed, help build solidarity among members. Our evidence shows that a crucial third logic was in play here: these publicly visible personal stories provide the all-important human interest narratives that professional journalists seek when framing their stories of economic hardship. The digital technologies that provide the structural foundations for the daily running of 38 Degrees have self-expressive behavioral norms and expectations embedded in their design. The movement continually encourages members to express personal and emotional responses throughout the campaign process. And yet, to have influence among policymakers and to carry the campaign 
beyond the hard core of activists, these frames must also find their way across the media system and be remediated in professional journalists' coverage.

From a Blogger to the Sun-via a Crowdfunded Expert Report

The next stage of the npower campaign provides further evidence of how 38 Degrees' repertoires integrate older and newer media logics. Two weeks after the petition launch, just as the campaign appeared to be fading, the Sun newspaper published a front-page article reporting in some detail how npower's alleged tax avoidance had been structured (Hawkes, 2013c). The energy company was accused of receiving loans from RWE, their German parent company, and funneling money through an intermediary in Malta. Npower was able to avoid corporation tax, the article alleged, by posting bottom-line 'losses' based on the significant cost of servicing these foreign loan repayments. 38 Degrees were quick to update their Facebook page to highlight the key facts from the Sun's new article (38 Degrees, 2013b).

What was the origin of the Sun's vital new information? The Sun's article did not happen by accident. In fact, it was based on a report published by the chartered accountant, financial adviser, and economic justice blogger, Richard Murphy. ${ }^{8}$ A couple of weeks earlier, upon reading about the 38 Degrees campaign on the day it was launched, Murphy had decided to write a blog post outlining his views on what he saw as the contradictions and dubious ethical foundation of npower's tax policy (Murphy, 2013). 38 Degrees core team spotted this online and, on the basis of that post they hired Murphy, whom it was agreed would be paid a consultancy fee to write a detailed report they might use to bolster their case. However, a crucial point here is that Murphy's professional fee was raised, not from 38 Degrees reserves, but from a rapidly-organized, crowdfunded online donation drive among its members. 
During our interviews with 38 Degrees members (see Appendix), the majority reported that the movement's aim to influence policy was central to their involvement. And the leadership perceives it as important to show their members when this involvement produces results. In this case, the leadership shared Murphy's report and the front page of the Sun in a member email, a blog post, and a Facebook update (shown in Figure 1), forging a direct link between the member donations that enabled the report and the tangible impact of a detailed investigation that would be 'read by millions' — in a professional media outlet (38 Degrees, 2013a). The member email also juxtaposed the effectiveness of individual member contributions - 'it's donations from 38 Degrees members that have uncovered this scam'with a new set of requests for action, including sending an email to npower chief Paul Massara. ${ }^{9}$ 
Figure 1. Building on professional media coverage to spur further engagement (38

Degrees, 2013a)

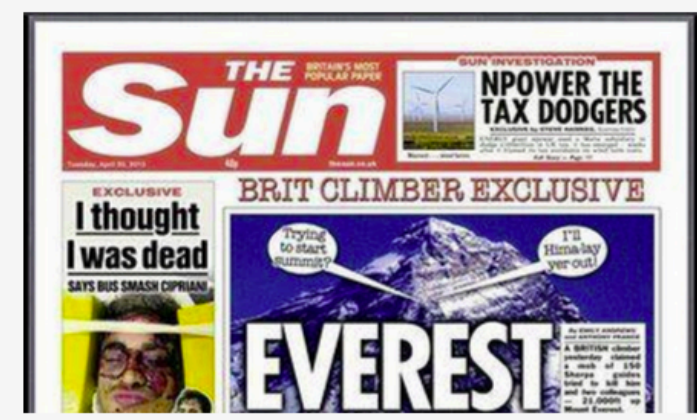

Npower have been rumbled! Over the past few days a top tax expert has been

investigating their accounts - paid for by 38 Degrees member. Today the results of that

investigation are splashed across the Sun newspaper - where it will be read by millions.

Click LIKE and SHARE to make sure more people see this!

We've got them. They're funneling profits made in the UK through a shell company in Malta. It looks like this has helped them dodge $£ 60$ million in tax over the last four years!

Click here to send Npower CEO Paul Massara an email demanding he meets with 38 Degrees members and tells us how he'll put an end to this immoral tax dodge:

Album: Timeline Photos

Shared with: 9 Public

Tag this Photo

Open Photo Viewer

Download

Embed Post

Report Photo

https://secure.38degrees.org.uk/email-npower-ceo

Generating Immediacy with the Two-Step Poll

After further Sun newspaper coverage reporting critical remarks from MPs and 'up to $£ 108$ million' of avoided tax by npower (Sun, 2013), and as the petition reached 170,000 signatures, npower chief Paul Massara invited 38 Degrees' director David Babbs to discuss the campaign with him, face to face. This was part of a broader strategy of crisis communication by the energy company (npower Press Office, 2013; E. Ward, 2013). 38 Degrees again linked this development to the influence of members' previous actions- 
signing the petition and funding the expert report that achieved mainstream media coverage: 'npower are rattled. They've seen their huge tax dodge splashed all across the media, and they're squirming under the pressure of more than 40,000 emails [from members to Paul Massara] and a 170,000+ signature petition' (Falcon, 2013a). And, faced with an invitation to meet npower boss Paul Massara in person, 38 Degrees' leadership did what they usually do with invitations that ask them to represent their members: they asked their members what to do.

A quick ad hoc online survey was created on the question of whether David Babbs should agree to the meeting and if he should insist that a small number of 38 Degrees members, who were npower customers, be present. But the Massara meeting survey was not an open call. Members were offered a range of alternatives: encourage people to move their energy accounts to an alternative supplier; contact local media to spread the campaign; contribute money to fund a national advertising campaign; and take part in a physical demonstration. Members were then encouraged to select their level of interest in each option, using a simple three-point scale. However, members were also given the opportunity to make their own suggestions in the free text section of the survey. This served to grant the leadership a mandate to create further and different enabling actions.

The survey results revealed that the majority favored a meeting between Massara and Babbs and a small group of 38 Degrees members. Babbs duly asked for a meeting (with these conditions stipulated) but his request was refused. Massara was prepared to meet Babbs, but not the 38 Degrees members. The entire email thread between Babbs and Massara was quickly shared with the 38 Degrees membership (Babbs, 2013). In the exchange, Babbs exercised a form of leadership by making his own view clear, but at the same time he was careful to state that the next step in the campaign would be decided by a poll of members: 'So, my personal view is that your (npower's) response is not really satisfactory. Ultimately 
though it's the view of your customers and 38 Degrees members that will decide what happens next with the campaign —I'll be asking them to vote shortly' (Babbs, 2013).

The vote was, in fact, another quick poll of members, but this time the question was narrowed to a clear yes or no decision on the most popular tactic from the first survey: a 'mass switch-off' away from npower and to alternative energy suppliers. ${ }^{10}$ An email with a simple button interface was sent to the full membership list (see Figure 2). Holding the voting open for just 48 hours created a heightened sense of immediacy.

\section{Figure 2: Step two in the two-step poll}

Is it time to teach Npower a lesson? 3 weeks ago they were exposed for not paying a single penny of corporation tax, while channeling UK profits through Malta. But they still haven't accepted they've done anything wrong. And, they keep refusing to meet us to discuss our concerns.[1]

Luckily Npower customers have got the trump card. We can hit them where it hurts: together we can take our custom elsewhere.

\section{So, time to vote - shall we launch a mass switch-off away from Npower now? Voting closes in $\mathbf{4 8}$ hours, so please vote now:}

\section{YES}

\section{NO}

Source: action@38degrees.org.uk FW: npower. Email sent May 14, 2013.

This two-step poll process is a common feature of 38 Degrees' approach to incorporating member opinion during campaigns. The first poll presents a relatively open list of alternative tactics and an opportunity for members to generate their own suggestions. The second poll simplifies the options and seeks a majority mandate for a specific course of action. 
The results of the online survey revealed overwhelming support for the next phase of the campaign, as 98 percent of respondents voted to launch a mass customer switch away from npower to alternative energy suppliers.

\section{The Switch}

The next phase of the campaign required those 14,000 members who were npower customers to send an email to the energy company explaining why they intended to move their accounts. 38 Degrees' leaders lined up six alternative energy providers, all of whom were selected on the grounds that they had unmistakable environmental or socially progressive credentials and a clean record of paying UK corporation tax. The descriptions of each company included customer ratings from the popular consumer watchdog Which, reinforcing the ethical consumerism logic of the campaign. The switch was designed as an individualized 'simple two-step process' that 'only takes 5 minutes' and was based on consumer logic — a direct loss of revenue for npower. ${ }^{11}$

For the large majority of members who were not npower customers, the leadership created an alternative path to involvement: an appeal to raise money to pay for a further old media-meets-new media tactic: a targeted online advertising campaign aimed at raising general public awareness of tax avoidance (Priestley, 2013). In order to reach beyond 38 Degrees' email list, these advertisements were placed on social media platforms and local news websites.

The Relationship Between 38 Degrees' Campaign Actions, Professional Media Coverage, and Twitter Discourse 
In the end, after over 180,000 petition signatures, 3,375 members pledged that they would move their energy accounts to a new provider. As the consumer switch became the center of the entire npower tax avoidance campaign, there was a small amount of coverage in the financial section of the Daily Mirror (Hiscott, 2013b) and the consumer section of the Guardian (Brignall, 2013). Despite several attempts by 38 Degrees staff to engage journalists (see for example 38 Degrees, 2013c), the campaign received no further exposure in professional media.

We can further see how important the ebb and flow of news coverage is to 38 Degrees by examining the relationship between campaign actions, professional media coverage, and Twitter discourse throughout the campaign. 
Figure 3: The relationship between 38 Degrees' campaign actions, professional media coverage, and Twitter discourse

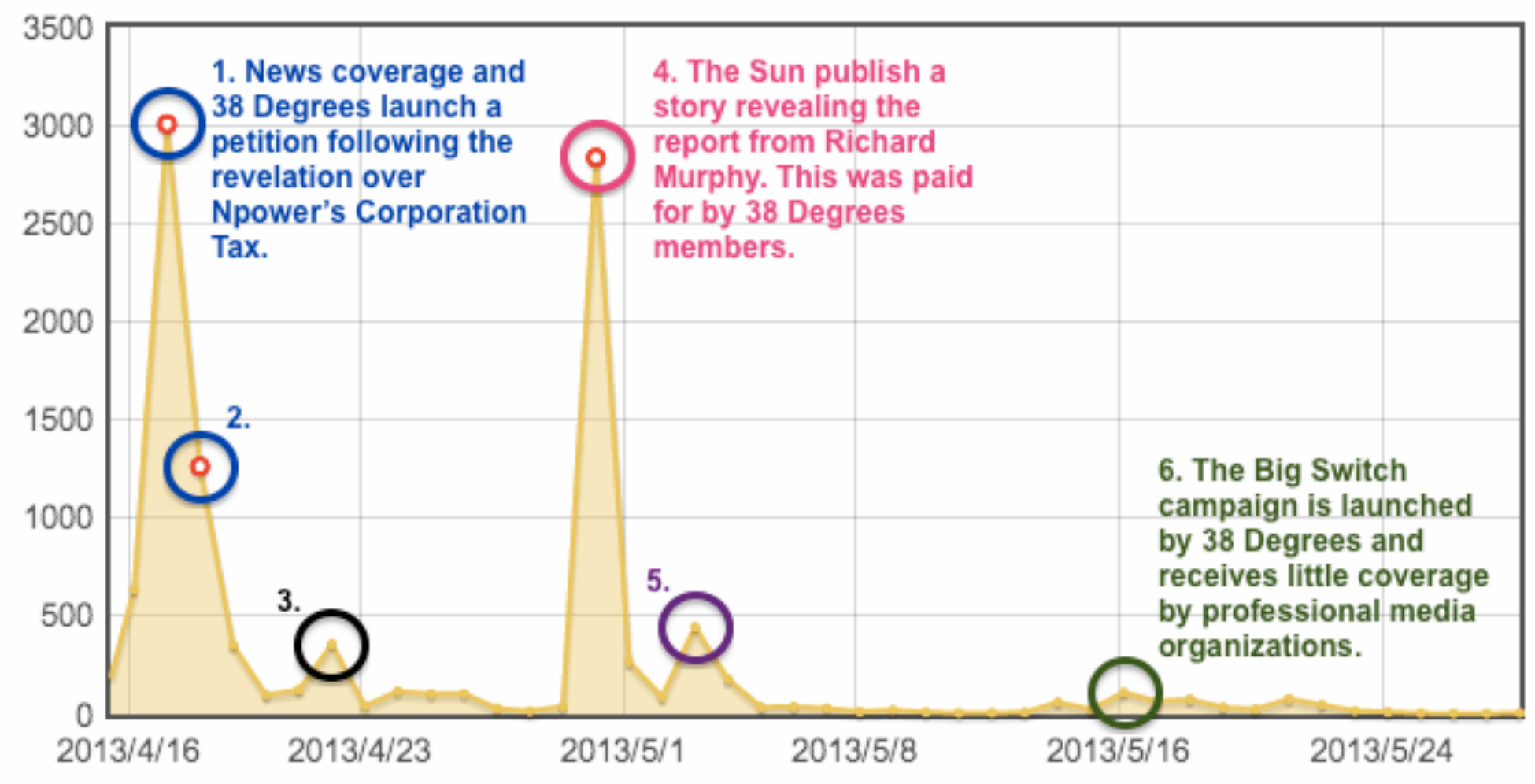

Source: Sysomos MAP.

Note: Tweets were collected from April 16 to May 28, 2013 through a strictly-defined Boolean keyword search, as follows: npower AND (tax OR 'tax dodging' OR 'tax-dodging' OR 38degrees OR ‘38 Degrees' OR ‘38_degrees' OR corporation OR taxes). This yielded 10,850 tweets in total 
As Figure 3 reveals, the significant increases in Twitter activity coincided with important moments of coverage from professional media.

If we probe a little deeper, six points on this chart reveal the strengths and the weaknesses of news cycle-driven temporal responsiveness. The spike at point 1 corresponds with the mainstream news coverage following the npower chief's appearance before the House of Commons Energy and Climate Change Select Committee. Point 2 is the launch of 38 Degrees' first online petition. If we skip to the fourth point, we can see the large spike on April 30. This follows the publication of the 38 Degrees-sponsored report by tax expert Richard Murphy, but more importantly the resulting front-page article in the Sun. A significant proportion of the Twitter mentions following this, at point 5 on May 3, came from users clicking the 'share on Twitter' button that appeared once they had signed the 38 Degrees online petition. This of course correlates with the increase in petition-signing following the Sun's article. However, as point 6 shows, the switch action, 38 Degrees' own little-reported initiative launched on May 16 to encourage people to move energy suppliers, failed to make an impact on Twitter.

Now, if we skip back to point 3 (April 22), we can see a small but significant rise in Twitter mentions of npower, tax dodging and 38 Degrees. Intriguingly, this emerged from tweets and retweets by several well-connected activist Twitter users, including Mark McGowen aka Artist Taxi Driver (Twitter name @ chunkymark, then with 30,600 followers) and UK Uncut (@UKUncut, with 70,500 followers) (McGowan, 2013; UK Uncut, 2013). This might lead to the conclusion that the campaign had a 'native' social media momentum of its own. But this would be a misleading interpretation, because at this point, too, the spur for these influential tweets was in fact a story in the Guardian about the appointment of former npower chief Volker Beckers to a non-executive directorship at the UK tax authority, HM Revenue and Customs (Macalister, 2013b). 


\section{Discussion and Conclusion}

38 Degrees’ Big Tax Turnoff campaign effectively came to an end in late May, 2013. We have no way of knowing how many 38 Degrees members switched their energy accounts away from npower. In the United Kingdom, moving energy providers is a complex and timeconsuming process, which, as the consumer complaint sections of news outlets reveal, contains great potential for bureaucratic error and wilful ignorance by energy companies. Equally, in this study, we have no means of assessing the precise behavioral impact of the emails sent by 38 Degrees' leadership.

As we have shown, 38 Degrees campaigns are, in part, a result of the leadership's sense of how their members' exposure to professionally-produced news will act as a spur to members' engagement. As their targeting of the Sun newspaper with the expert report detailing npower's tax avoidance makes clear, gaining publicity in professional media is important for success. There are questions, then, about whether HMM actions can be sustained solely in the realm of digital tools like online petitions, email surveys, and viral social media sharing. Such uses of technology are mostly presented in scholarly work on digital media and mobilization as exogenous to a movement's relationship with professional media (though for a useful exception see Mattoni and Treré, 2014). Professional media retain a powerful role in shaping agendas and legitimizing and authorizing political action. Digital technologies create many genuinely important and different opportunities for non-elite interventions in shaping agendas, but as we have shown, these interventions are predicated on the very existence of professional media in the first place. If the agenda of professional news 
organizations moves on, as it did in late May 2013, a campaign can start to wither. This is what happened with the switch campaign.

Organizational capacity and leadership still matter a great deal in these contexts. We are not arguing that this must come from formal, bureaucratically-maintained organizations. But 38 Degrees' central team must deliberately create the digital network repertoires that enable their members to engage and express their preferences. And they must do so in ways that allow for these actions to be visibly represented back to the movement's own mass membership, and to the public and professional media, all in ways that generate the thrill of immediacy. How 38 Degrees works therefore puts another significant dent in the one-sizefits-all 'organizing without organizations' approach that has become popular among some observers of digital politics in recent years (see for example Shirky, 2008, Margetts et al, 2015). Leaving organizational and leadership variables out of analyses of internet-enabled mobilizations is like describing a house by referring only to the contents of a single room. What Bennett and Segerberg identified as 'crowd-enabled' 'connective' action is important for digitally-enabled political mobilization but, as they themselves are keen to stress, this is just one among several types of action. 38 Degrees clearly does not belong in the crowdenabled category but nor is it traditional collective action involving organizational brokering, heavy central coordination, and ideologically-coherent collective action frames. 38 Degrees fits with the HMM type first identified in MoveOn in the United States (Chadwick, 2007; Karpf, 2012) and it has some overlaps with what Bennett and Segerberg term 'organizationally-enabled connective action' (2013). ${ }^{12}$

We have also shown that the horizontalist digital media logics of 38 Degrees are interdependent with professional news media logics, even the logics of daily print media. 38 Degrees take cues from their members' digitally-expressed multi-issue priorities but they must also take cues from those who wield substantial influence in the media system: 
professional journalists working in mass audience outlets. We find this to be important not only due to the point that lack of integration with professional news media leads to lack of coverage for a cause - a prominent theme in social movement studies (Gamson and Wolfsfeld, 1993; Gitlin, 1980; Rucht, 2004)_but more significantly because lack of coverage tends to undermine members' collective sense of the efficacy of their actions and a campaign's legitimacy. This is because the leadership has much weaker 'mainstream' evidence of members' efficacy that it can present back to members. Polls, petitions, likes, shares, retweets, and crowdfunding lead to professional media impact, increasing the likelihood of member action in further polls, petitions, likes, shares, retweets, and crowdfunding, and on it goes. When this circle is broken, momentum is lost. In this case, the circle was broken by professional media.

The 38 Degrees central staff perform important filtering and gatekeeping roles and their influence over the design of actions enables them to exercise significant power. At the same time, we need to be clear: 38 Degrees is not an elite-dominated think tank or lobbying group that relies only on professional media networks while 'astroturfing' its way through life, masquerading as a member-driven grassroots movement. The central team use their power to provide structure to the inchoate, individualized, and often affective responses of their members to matters of public concern. Given the diversity of campaigns, individual members choose those campaigns they wish to promote and support. This self-determination was also noted by a number of our member interviewees as a key reason for getting involved (Interview 9, June 2013; Interview 13, June 2013). 38 Degrees therefore behaves like other HMMs: it capitalizes on the decline of collective identity frames by offering personalized pathways to engagement (Kavada, 2012, p. 44; Karpf, 2012; Vromen, 2008; 2015, p. 196). Thus, in line with research that suggests engagement is increasingly personallydefined and focused on issues of importance to the individual rather than institutionally- 
derived and patterned by older, more coherent ideologies of modernity, ${ }^{13}$ these personalized forms of communication are a means by which HMMs motivate their large, dispersed memberships. The use of digital media to perpetually involve their membership in binding strategic decisions is unique to hybrid mobilization movements and 38 Degrees fits the mold of MoveOn (Carty, 2010; Eaton, 2010; Karpf, 2012), Avaaz (Kavada, 2012), and GetUp! (Vromen, 2015; Vromen and Coleman, 2013).

Gerbaudo (2012) has argued that the essence of digitally-mediated activism is 'choreographical leadership,' which he argues relies on 'scene-setting' and 'scripting' by 'influential Facebook admins and activist tweeps' (Gerbaudo, 2012, p. 13). 38 Degrees' central staff might be seen as 'choreographers' who set the scene by organizing and structuring action while trying to minimize their influence on the wills of individual members. Thus our findings differ from those of Eaton (2010), whose study of MoveOn found evidence of top-down 'manufactured' community. It is the mass of individual participants who shape 38 Degrees' strategy, with their digitally-mediated interventions in internal online polls, often many months in advance of specific campaigns. But it is the leaders who offer the technological capacity and work required to design the ongoing consultations, structure appealing and meaningful action, and activate latent ties when the time is right. Using targeted email, Facebook and Twitter monitoring, blog posts, online polls, and petitions, the leadership assimilates the fragmented individual voices of its membership, generates important moments of cohesion among the chaos, and presents these to professional media and policy makers.

But we need to be clear about what structures these moments of cohesion. We see the oscillations between choreographic leadership and member influence, and between digital media horizontalism and elite media-centric work as the space of interdependencies in which 38 Degrees acts. Interdependence with professional media, in particular, has not been 
adequately recognized in previous research. ${ }^{14}$ This matters because, as we have shown, when interdependence turns to dependence, it is more likely that a 38 Degrees campaign will lose momentum. This space of interdependencies model could be used to guide research on other campaigns and on HMMs and digital mobilization more generally.

This raises a broader point about appropriate research foci as the interplay between digital media and political engagement continues to evolve in the post-Arab Spring, postOccupy, and post-Indignados era. As time passes, movements like 38 Degrees, MoveOn, Avaaz, GetUp!, and SumOfUs are starting to look like long-term bets. They are the success stories of digitally-enabled activism; the survivors.

With this longevity in mind, we conclude with a hopeful, though admittedly speculative point. Given that the inchoate affective responses aggregated by 38 Degrees' leadership will often emerge from individuals' sense of outrage at stories that emerge in the passing parade of the daily news, we need to be clear about the positive significance of the movement's role in the mediated structures of contemporary British democracy. In his classic critique of mass broadcast media logic, Postman (2005, pp. 68-69) introduced the concept of the 'information-action ratio.' For many citizens, Postman said, the shift to a mass news environment characterized by flows of abundant 'context-free' information shaped by centralized producers of entertainment and novelty dismantles the link between information and action. The result is what Postman termed a 'great loop of impotence' generated by our ability to access and consume vast, regularly updated quantities of 'superficial facts' without being able to meaningfully act upon them. Postman condensed this with a provocation: 'How often does it occur that information provided you on morning radio or television, or in the morning newspaper, causes you to alter your plans for the day, or to take some action you would not otherwise have taken, or provides insight into some problem you are required to solve? $[\mathrm{M}]$ ost of our daily news is inert, consisting of information that gives us something to 
talk about but cannot lead to any meaningful action.' 38 Degrees are interdependent with, and sometimes dependent upon, professional news media. But what is different here is that they also use digital media to overcome the potential for passivity among their members and to introduce their members' voices into news cycles. They provide articulations between the incessant flow of news media and atomized citizens' 'cries in the wilderness' that rightly generated such fierce criticisms of mediated politics during the twentieth century era of mass media.

Professor Andrew Chadwick is Professor of Political Science and Co-Director of the New Political Communication Unit in the Department of Politics and International Relations at Royal Holloway, University of London. Email: andrew.chadwick@,rhul.ac.uk; Website: http://www.andrewchadwick.com; Twitter: http://twitter.com/andrew chadwick

Dr James Dennis is a postdoctoral research assistant in the New Political Communication Unit in the Department of Politics and International Relations at Royal Holloway, University of London. Email: james.dennis.2010@live.rhul.ac.uk; Website: http://www.jameswilldennis.com; Twitter: https://twitter.com/jameswilldennis 


\section{References}

38 Degrees (2013a) Npower Have Been Rumbled! [online]. Facebook update. Available from:

https://www.facebook.com/photo.php?fbid=10152789127170788\&set=a.4572557657

87.382103.200006375787\&type=1 [Accessed 24 March 2014].

38 Degrees (2013b) Npower's tax dodging explained [online]. Facebook update. Available from:

https://www.facebook.com/photo.php?fbid=10152789416335788\&set=a.4572557657 87.382103.200006375787\&type=1 [Accessed 23 March 2014].

38 Degrees (2013c)@Grahamhiscott Tax dodging is in the news today \& right now \#38Degrees members are switching from tax dodgers \#Npower http://38d.gs/TaxTurnoff [online]. Tweet. Available from: https://twitter.com/38_degrees/status/335020990583156738 [Accessed 24 March 2014].

38 Degrees (2015) 'Thank You.' Email sent 23 December 2015. [Accessed 23 December 2015].

Ashton, E. (2013) Energy giant pays zero tax [online]. Sun Website. Available from: http://www.thesun.co.uk/sol/homepage/news/politics/4891267/Energy-giant-Npowerpays-zero-corporation-tax.html [Accessed 10 May 2013].

Babbs, D. (2013) NPOWER: 48 HRS TO VOTE [online]. 38 Degrees Website. Available from: http://blog.38degrees.org.uk/2013/05/14/npower-48-hrs-to-vote/ [Accessed 22 May 2013].

Bennett, W. L. (1998) 'The UnCivic Culture: Communication, Identity, and the Rise of Lifestyle Politics', Political Science and Politics, 31 (4), 41-61. 
Bennett, W. L. (2012) 'The Personalization of Politics: Political Identity, Social Media, and Changing Patterns of Participation', The Annals of the American Academy of Political and Social Science, 644 (20), 20-39.

Bennett, W. L. and Segerberg, A. (2013) The Logic of Connective Action: Digital Media and the Personalization of Contentious Politics. New York: Cambridge University Press.

Bimber, B. (2003) Information and American Democracy: Technology in the Evolution of Political Power. Cambridge: Cambridge University Press.

Bimber, B., Flanagin, A. J. and Stohl, C. (2005) 'Reconceptualizing Collective Action in the Contemporary Media Environment', Communication Theory, 15 (4), 365-388.

Bimber, B., Flanagin, A. J. and Stohl, C. (2012) Collective Action in Organizations: Interaction and Engagement in an Era of Technological Change. Cambridge: Cambridge University Press.

Brignall, M. (2013) Npower feels the heat after accusations of UK tax avoidance [online]. Guardian Website. Available from: http://www.theguardian.com/money/2013/may/18/npower-heat-accusations-taxavoidance [Accessed 20 May 2013].

Carty, V. (2010) 'Bridging Contentious and Electoral Politics: MoveOn and the Digital Revolution' Research in Social Movements, Conflict and Change 30, 171-196.

Chadwick, A. (2007) 'Digital Network Repertoires and Organizational Hybridity', Political Communication, 24 (3), 283-301.

Chadwick, A. (2013) The Hybrid Media System: Politics and Power. Oxford: Oxford University Press.

Compton, S. (2013) NPOWER: PAY YOUR TAX [online]. 38 Degrees Website. Available from: http://blog.38degrees.org.uk/2013/04/17/npower-pay-your-tax/ [Accessed 22 May 2013]. 
Dalton, R. J. (2008) Citizens Politics: Public Opinion and Political Parties in Advanced Industrial Democracies, fifth edition. Washington DC: CQ Press.

Department of Energy and Climate Change (2014) Annual Domestic Energy Bills. Available from: https://www.gov.uk/government/statistical-data-sets/annual-domestic-energyprice-statistics [Accessed 3 December 2015).

Della Porta, D. and Diani, M. (2006) Social Movements: An Introduction, second edition. Oxford: Blackwell.

Earl, J. and Kimport, K. (2011) Digitally Enabled Social Change: Activism in the Internet Age. Cambridge MA: MIT Press.

Eaton, M. (2010) 'Manufacturing Community in an Online Activist Organization: The Rhetoric of MoveOn.org's Emails', Information, Communication \& Society, 13 (2), 174-192.

Falcon, R. (2013) NPOWER'S EXCUSES DON'T STAND UP [online]. 38 Degrees Website. Available from: http://blog.38degrees.org.uk/2013/05/21/npowers-excuses/ [Accessed 22 May 2013].

Flanagin, A. J., Stohl, C. and Bimber, B. (2006) 'Modeling the Structure of Collective Action' Communication Monographs 73 (1), 29-54.

Gamson, W. A. and Wolfsfeld, G. (1993) 'Movements and Media as Interacting Systems' The Annals of the American Academy of Political and Social Science 528 (1), 114125.

Geertz, C. (1973) The Interpretation of Cultures: Selected Essays by Clifford Geertz. New York: Basic Books.

Gerbaudo, P. (2012) Tweets and the Streets: Social Media and Contemporary Activism. London: Pluto Press.

Giddens, A. (1991) Modernity and Self-identity: Self and Society in the Late Modern Age. 
Cambridge: Polity.

Gitlin, T. (1980) The Whole World is Watching: Mass Media in the Making and Unmaking of the New Left. Berkeley: University of California Press.

Hawkes, S. [steve_hawkes] (2013a) Npower's charm offensive likely to be slightly derailed by admission they haven't paid any corporation tax for 3 years .. [online]. Tweet. Available from: https://twitter.com/steve_hawkes/status/324142448760733696 [Accessed 20 March 2014].

Hawkes, S. (2013b) Ditch Npower over tax trick [online]. Sun Website. Available from: http://www.thesun.co.uk/sol/homepage/news/money/article4892586.ece [Accessed 10 May 2013].

Hawkes, S. (2013c) Watt? No tax? Npower avoids paying £108m to HMRC by funnelling massive sum to German owners via Malta [online]. Sun Website. Available from: http://www.thesun.co.uk/sol/homepage/news/money/4908225/Npower-avoidspaying-108m-tax-by-funnelling-funds-to-Malta.html [Accessed 10 May 2013].

Hiscott, G. (2013a) Npower petition signed by 80,000 people while energy giant reveals it HAS paid some corporation tax [online]. Daily Mirror Website. Available from: http://www.mirror.co.uk/news/uk-news/npower-petition-signed-80000-people1840274 [Accessed 20 March 2014].

Hiscott, G. (2013b) Npower targeted by pressure group 38 Degrees over tax [online]. Daily Mirror Website. Available from: http://www.mirror.co.uk/money/city-news/npowertargeted-pressure-group-38-1893752 [Accessed 20 March 2013].

Inglehart, R. (1990). Culture Shift in Advanced Industrial Society. Princeton NJ: Princeton University Press.

Jarvis, B. (2013) NPOWER: WE'RE CAUSING A SPLASH [online]. 38 Degrees Website. Available from: http://blog.38degrees.org.uk/2013/04/19/npower-were-causing-a- 
splash/ [Accessed 22 May 2013].

Karpf, D. (2012) The MoveOn Effect: The Unexpected Transformation of American Political Advocacy. Oxford: Oxford University Press.

Kavada, A. (2012) 'Engagement, bonding, and identity across multiple platforms: Avaaz on Facebook, YouTube, and MySpace', MedieKultur, 28 (52), 28-48.

Macalister, T. (2013a) Npower faces customer anger as petition calls for full payment of taxes [online]. Guardian Website. Available from: http://www.theguardian.com/business/2013/apr/18/npower-faces-anger-tax-petition [Accessed 20 March 2014].

Macalister, T. (2013b) Storm brews over energy price rises and HMRC appointment of npower chief [online]. Guardian Website. Available from: http://www.theguardian.com/business/2013/apr/22/energy-price-rises-hmrc-npower [Accessed 23 March 2014].

Margetts, H., John, P., Hale, S. and Yasseri, T. (2015) Political Turbulence: How Social Media Shape Collective Action. London: Princeton University Press.

Mattoni, A. and Treré, E. (2014) 'Media Practices, Mediation Processes, and Mediatization in the Study of Social Movements', Communication Theory, 24 (3), 252-271.

McGowan, M. [chunkymark] (2013) OMFG!!! HMRC hires non tax paying chief from NPower...they are just laughing at us!!! http://www.guardian.co.uk/business/2013/apr/22/energy-price-rises-hmrc-npower [online]. Tweet. Available from: https://twitter.com/chunkymark/status/326227184287113216 [Accessed 24 March 2014].

Murphy, R. (2013) nPower's tax and why 38 Degrees are right to protest [online]. Tax Research Blog. Available from: 
http://www.taxresearch.org.uk/Blog/2013/04/18/npowers-tax-and-why-38-degreesare-right-to-protest/ [Accessed 23 April 2014].

Norris, P. (2011) Democratic Deficit: Critical Citizens Revisited. Cambridge: Cambridge University Press.

npower Press Office (2013) npower response to 38degrees campaign [online]. Npower Website. Retrieved 23/03/2013. Available from:

http://www.npowermediacentre.com/Press-Releases/npower-response-to-38degreescampaign-1243.aspx [Accessed 23 March 2013].

Postman, N. (2005) Amusing Ourselves to Death: Public Discourse in the Age of Show Business, $20^{\text {th }}$ anniversary edition. New York: Viking. (Orig. Pub. 1985).

Priestley, R. (2013) NPOWER: ONLINE ADVERTISING [online]. 38 Degrees Website. Available from: http://blog.38degrees.org.uk/2013/05/21/npower-online-advertising/ [Accessed 22 May 2013].

Rucht, D. (2004). 'The Quadruple 'A': Media Strategies of Protest Movements Since the 1960s', in W. Van de Donk, B. D. Loader, P. G. Nixon, \& D. Rucht (eds.), Cyberprotest: New Media, Citizens and Social Movements. London, New York: Routledge, pp. 29-56.

Shirky, C. (2008) Here Comes Everybody: the Power of Organizing Without Organizations. London: Allen Lane.

Sun (2013) Furious MP demands npower tax probe as 8 in 10 Brits now less likely to use giant [online]. Sun Website. Available from: http://www.thesun.co.uk/sol/homepage/news/money/4909718/MP-demands-npowertax-probe.html [Accessed 10 March 2014].

UK Uncut (2013) Awkward-@George_Osborne has hired ex boss of \#Npower the tax dodging energy company to oversee HMRC! Take action with@EDFOFF [online]. Tweet. Available from: https://twitter.com/UKuncut/status/326295510510096387 
[Accessed 24 March 2014].

Vromen, A. (2008) 'Political Change and the Internet in Australia: Introducing GetUp', in T. Häyhtiö and J. Rinne (eds.) Net Working/Networking: Citizen Initiated Internet Politics. Tampere: Tampere University Press, pp. 103-126.

Vromen, A. (2015) 'Campaign Entrepreneurs in Online Collective Action: GetUp! in Australia', Social Movement Studies, 14 (2), 195-213.

Vromen, A. and Coleman, W. (2013) 'Online Campaigning Organizations and Storytelling Strategies: Getup! in Australia', Policy and Internet, 5 (1), 76-100.

Vasi, I. B., Walker, E. T., Johnson, J. S. and Tan, H. F. (2015) “"No Fracking Way!” Documentary Film, Discursive Opportunity, and Local Oppposition against Hydraulic Fracturing in the United States, 2010 to 2013', American Sociological Review. OnlineFirst: DOI: 10.1177/0003122415598534 http://asr.sagepub.com/content/early/2015/08/12/0003122415598534.full.pdf

Ward, E. (2013) Talking Tax - an updated message from Paul Massara [online]. Npower Website. Available from: https://blog.npower.com/2013/05/talking-tax-update-fromnpower-ceo-paul-massara/ [Accessed 17 May 2013].

Zald, M. N. and Ash, R. (1966) 'Social Movement Organizations: Growth, Decay and Change', Social Forces, 44 (3), 327-341. 


\section{Appendix: List of 38 Degrees Emails and Interviews}

\section{Emails}

All sent from the action@,38degrees.org.uk address:

npower. Sent 17/04/2013.

npower: Can you help? Sent 26/04/2013.

Scandalous. Sent 30/04/2013.

npower update. Sent 03/05/2013.

FW: npower. Sent 14/05/2013.

npower vote now. Sent 15/05/2013.

npower: Switch now. Sent 16/05/2013.

npower. Sent 17/05/2013.

npower: Switch now. Sent 17/05/2013.

npower. Sent 21/05/2013.

npower: Join in now. Sent 21/05/2013.

npower. Sent 22/05/2013.

npower: Join in now. Sent 22/05/2013.

npower. Sent 28/05/2013.

\section{Interviews}

Anonymity was offered as part of the agreement allowing internal access to 38 Degrees. The gender of staff interviewees should not be implied from their pseudonyms.

Interviews with 38 Degrees Staff

\begin{tabular}{|l|l|l|l|}
\hline & Pseudonym & Role & Date \\
\hline & & & \\
\hline 1 & 'Jessica' & Member Services Manager & May, 2013 \\
\hline 2 & 'Anna' & Campaigns By You Manager & May, 2013 \\
\hline 3 & 'Jonathan' & Campaigns Manager & May, 2013 \\
\hline 4 & 'Amy' & Campaigns Director & May, 2013 \\
\hline 5 & 'Adam' & Technology Manager & May, 2013 \\
\hline 6 & 'Paul' & Campaigner & May, 2013 \\
\hline 7 & David Babbs & Executive Director & June, 2013 \\
\hline
\end{tabular}


Interviews with 38 Degrees Members

\begin{tabular}{|l|l|l|l|l|l|}
\hline & Pseudonym & Age & City & Profession & Date \\
\hline 8 & 'Claire' & 25 & Leicester & $\begin{array}{l}\text { Archive centre } \\
\text { operative }\end{array}$ & June, 2013 \\
\hline 9 & 'Mike' & 24 & London & NGO worker & June, 2013 \\
\hline 10 & 'Daniela' & 21 & London & Student & June, 2013 \\
\hline 11 & 'Siobhan' & 20 & London & Student & June, 2013 \\
\hline 12 & 'Nina' & 22 & London & Unemployed & June, 2013 \\
\hline 13 & 'Geraldine' & 68 & Liverpool & Retired & June, 2013 \\
\hline 14 & 'Helen' & 49 & Essex & Civil servant & July, 2013 \\
\hline 15 & 'George' & 63 & Birmingham & Retired & August, 2013 \\
\hline 16 & 'Mary' & 63 & Hertfordshire & Retired & October, 2013 \\
\hline 17 & 'Ian' & 60 & Brighton & Teacher & October, 2013 \\
\hline 18 & 'Jack' & 56 & London & Civil Servant & October, 2013 \\
\hline 19 & 'Liam' & 38 & London & Charity sector & October, 2013 \\
\hline 20 & 'Joanna' & 57 & Essex & Volunteer & October, 2013 \\
\hline 21 & 'Joan' & 73 & London & Artist & October, 2013 \\
\hline 22 & 'Danni' & 24 & London & Advertising & November, 2013 \\
\hline
\end{tabular}

\section{Notes}

${ }^{1}$ For book length treatments see Bennett \& Segerberg, 2013, Bimber, 2003, Bimber, et al., 2012, Earl \& Kimport, 2011, Gerbaudo, 2012, Karpf, 2012, and Margetts et al, 2015.

${ }^{2}$ Bimber et al, 2012, Carty, 2010; Chadwick, 2006, pp. 122-124; Chadwick, 2007, Flanagin et al, 2006, Karpf, 2012.

${ }^{3}$ By using the term movement, we make the basic point that the operational norms of HMMs differ from those of political parties and traditional interest organizations. At the same time, we recognize that due to their clearly identifiable core leadership groups HMMs also differ in important ways from 'classical' social movement formations (for an overview of social movements see Della Porta and Diani, 2006). A minimal amount of organizational maintenance and some clearly defined central staff roles are important for the functioning of HMMs. In this regard, they share some traits with what are often termed "social movement organizations" (for the seminal approach see Zald and Ash, 1966). Nevertheless, we are not convinced that this fully captures how 38 Degrees actually works. Its campaigns cover such a wide range of issues, and combine relatively weak leadership norms and minimal bureaucracy and staff with a conscious strategy to devolve strategic power to non-elite supporters. In short, 38 Degrees is a movement, but not in most of the conventional senses 
established in social movement studies. We are grateful to one of the anonymous reviewers for pointing out the ambiguities of the term.

${ }^{4}$ Bimber et al, 2012; Carty, 2010; Eaton, 2010; Karpf, 2012; Kavada, 2012; Vromen, 2008, 2015.

${ }^{5}$ For transcript and video of the hearings see http://www.parliament.uk/business/committees/committees-a-z/commons-select/energy-andclimate-change-committee/inquiries/parliament-2010/energy-prices-profits-and-poverty [accessed December 3, 2015].

${ }^{6}$ These data are from the UK industry standard body ABC: http://www.abc.org.uk

7 'npower: Can you help?' Email sent April 26, 2013. Bold in original. Italics added by us for emphasis.

${ }^{8}$ Murphy blogs at http://www.taxresearch.org.uk/Blog. In September 2015 he became a visiting professor at City University in London.

9 'Scandalous.' Email sent April 30, 2013. Different versions of the email were distributed according to whether the recipient had already signed the online petition. Actions included emailing the CEO of npower; a reminder to sign the petition; share the petition on Facebook; or tweet the@npowerhq account.

10 'FW: npower.' Email sent May 14, 2013.

11 'npower: Switch now.' Email sent May 16, 2013.

${ }^{12}$ Margetts et al (2015) do not integrate organizational capacity and leadership. 38 Degrees were involved in several of the UK petition campaigns they use as examples but do not appear in their analysis.

${ }^{13}$ See for example Bennett, 2012, Dalton, 2008, Giddens, 1991, Inglehart, 1990, and Norris, 2011.

${ }^{14}$ Journalists and professional media organizations are entirely absent from Margetts et al's (2015) analysis.

${ }^{15}$ Given his role within 38 Degrees, David Babbs agreed to be interviewed without anonymity. 